\title{
ANALISIS KORELASI PEMANFAATAN HASIL PERKEMBANGAN TEKNOLOGI INFORMASI TERHADAP TINGKAT KELULUSAN MAHASISWA PADA FAKULTAS EKONOMI UNIVERSITAS PAKUAN BOGOR
}

\author{
Satsangkaryon \\ Dosen Tetap Fakultas Ekonomi Universitas Pakuan
}

\begin{abstract}
ABSTRAK
Perkembangan teknologi informasi (TI) saat ini sangat pesat dan dampaknya terhadap proses belajar mahasiswa dapat bersifat postif dan negatif. Dari data kelulusan mahasiswa tahun 2009/2010 diketahui mahasiswa dengan kelulusan "Lebih cepat" dan "Tepat Waktu" sebanyak 32,79\%, tahun 2010/2011 sebanyak 21,12\% dan tahun 2011/2012 sebanyak 25,54\% sisanya dengan kelulusan "Terlambat" dan "Sangat Terlambat" berarti mahasiswa Fakultas Ekonomi Unpak sebagian besar kurang bekerja keras untuk mempercepat kelulusannya. Berdasarkan jawaban dari 100 orang responden, yaitu mahasiswa Fakultas Ekonomi Unpak tahun 2009/2010 dan 2010/2011 diketahui sebanyak 74\% menyatakan "cukup setuju" bahwa mereka telah memanfaatkan hasil TI dalam proses belajar untuk memperoleh jawaban ujian atau plagiat dan mereka termasuk dalam prakiraan kelulusan kategori "terlambat" (27\%) dan "sangat terlambat" (7\%). Mereka yang menyatakan "cukup setuju" untuk menyalahgunakan hasil TI dan dikategorikan berperilaku "sedang" (81\%) sehingga dapat disimpulkan bahwa penyalahgunaan hasil TI dan perilaku mahasiswa mempunyai korelasi terhadap tingkat kelulusan mahasiswa. Berdasarkan uji korelasi diperoleh hasil $\mathrm{rs}=.242$ dan $\mathrm{P}_{-}$value 0.15 atau lebih kecil dari 0,05 dan berdasarkan uji regresi berganda diperoleh hasil $\mathrm{R}=37,9 \%(\mathrm{R}$ square $=14,4 \%$ ) sehingga dapat disimpulkan bahwa Tingkat Perilaku dan Tingkat Penyalahgunaan TI mempunyai korelasi cukup siginifikan terhadap tingkat kelulusan.
\end{abstract}

Kata kunci: Prakiraan Kelulusan Mahasiswa, Perilaku, Penyalahgunaan hasil Teknologi Informasi

\begin{abstract}
The development of information technology (IT) is now very rapidly and their impact on student learning can be both positive and negative. From the data graduation in 2009/2010 known to students with graduation "Faster" and "On Time" as much as 32.79\%, 21.12\% in 2010/2011 and 2011/2012 as much as $25.54 \%$ of them with graduation " Too late "and" It's Too late "means the Faculty of Economics Unpak mostly less working hard to speed up graduation. Based on the answers of 100 respondents, namely the Faculty of Economics students in 2009/2010 and 2010/2011 Unpak known as much as 74\% stated "quite agree" that they have made use of IT results in the learning process to obtain answers to the exam or the plagiarism and those included in the forecast graduation category of "late" (27\%) and "very late" (7\%). Those who expressed "quite agree" to abuse the results of IT and categorized behave "moderate" (81\%) so that it can be concluded that the abuse of IT results and student behavior are correlated to the level of graduation. Based on the results obtained correlation $r s=.242$ and $P_{-}$value of $0: 15$ or less than 0.05 and based on regression test result $R=37.9 \%(R$ square $=14.4 \%)$ so it can be concluded that the rate of Conduct and Level IT misuse has relatively strong correlation to the level of graduation.
\end{abstract}

Keywords: Estimated Graduate Student, Behavior, Information Technology Misuse results

\section{Pendahuluan}

Perkembangan teknologi informasi pada era sekarang ini sangat pesat sekali, meliputi inovasi perangkat keras (hardware) dan perangkat lunak (software) untuk memenuhi ekspektasi pelanggan (customers). Inovasi pengembangan perangkat keras 
teknologi informasi pada saat ini telah menghasilkan suatu temuan perangkat keras yang lebih kecil, ringan namun memiliki kemampuan yang tinggi sehingga dapat memenuhi harapan pengguna, yaitu peralatan komunikasi yang kecil, ringan tetapi memiliki kemampuan besar. Demikian juga perkembangan perangkat lunak menunjukan perkembangan yang cukup signifikan meliputi sistem operasi, program aplikasi maupun programprogram lainnya, hal tersebut didorong adanya persaingan di antara para pengembang software yang menuntut inovasi secara terus menerus agar dapat menghasilkan perangkat lunak yang sesuai dengan kemampuan pengguna (user friendly). Dengan demikian perkembangan teknologi informasi telah memenuhi harapan pengguna (users) baik pihak penyebar/penyampai informasi dan penerima informasi, penyebar informasi mengunggah (upload) informasi yang diinginkan sehingga tersedia di dunia maya (virtual) dengan jumlah relatif lengkap dan beragam, mulai dari yang positif sampai dengan yang negatif. Selanjutnya informasi dalam dunia maya tersebut dapat dengan mudah diakses oleh masyarakat luas siapa saja, kapan saja dan dimana saja, seolah-olah tanpa ada batasan ruang dan waktu. Jadi kemajuan teknologi informasi sebagaimana diuraikan di atas dapat memberikan manfaat yang sangat besar terhadap perkembangan dunia informasi, yaitu semua pihak diuntungkan baik pihak pengirim informasi, yaitu dengan kemudahan untuk menyampaikan informasi maupun pihak penerima yaitu kemudahan memperoleh/mendapatkan informasi, meskipun tidak dipungkiri ada beberapa pihak yang menyalahgunakan hasil tekonologi informasi tersebut digunakan untuk hal-hal yang bertentangan dengan ketentuan dan norma-norma yang berlaku.

Para pengguna hasil perkembangan teknologi informasi di antaranya adalah para mahasiswa yang menggunakan ketika mengikuti proses pembelajaran, antara lain untuk mendapatkan informasi dalam rangka menyusun tugas-tugas perkuliahan, penyampaian informasi antarteman dan penyajian materi danlain sebagainya, namun di samping itu juga ada peluang mahasiswa dapat menyalahgunakan hasil teknologi informasi untuk hal-hal yang bertentangan dengan ketentuan dan norma yang berlaku. Dengan demikian hasil perekembangan teknologi informasi dapat dimanfaatkan oleh para mahasiswa untuk hal-hal yang bersifat positif dan negatif sangat tergantung pribadi masing-masing mahasiswa.

Pemanfaatan terhadap hasil perkembangan teknologi informasi secara positif oleh mahasiswa antara lain:

1. Mendapatkan informasi yang dibutuhkan;

2. Komunikasi timbal balik antarmahasiswa atau dengan dosen;

3. Sarana diskusi;

4. Sedangkan yang termasuk dalam pemanfaatan hasil perkembangan teknologi informasi secara negatif oleh mahasiwa antara lain;

5. Publikasi informasi yang tidak benar/menyesatkan;

6. Plagiat karya ilmiah;

7. Kecurangan mencari jawaban dari internet pada saat dilaksanakan ujian atau tes;

8. Bertanya/menginformasikan jawaban kepada teman pada saat berlangsung ujian/test

Atas dasar uraian tersebut di atas dapat diketahui bahwa pemanfaatan atas hasil perkembangan teknologi informasi oleh para mahasiswa apabila 
tidak diantisipasi/dikendalikan dengan baik berakibat pemanfaatan hasil teknologi informasi secara salah sehingga secara tidak langsung membuat mahasiswa tidak mau bekerja keras untuk dapat lulus dengan nilai baik melainkan ingin berhasil tapi dengan cara mudah yaitu dengan cara memanfaatkan hasil perkembangan teknologi secara salah, apabila hal ini dibiarkan terus menerus maka akan menghasilkan sumber daya manusia yang berintergritas rendah.

Berdasarkan pengalaman Penulis sebagai Dosen, Penguji Seminar dan Pembimbing penyusunan karya tulis skripsi pada Fakultas Ekonomi Universitas Pakuan Bogor, sejak tahun 2000 sampai sekarang, banyak ditemui hal sebagai berikut:
1. Jawaban ujian UTS atau UAS oleh sebagian besar mahasiswa adalah sama.

2. Materi makalah seminar dan skripsi sama atau hanya berbeda nama perusahaan dan tahunnya.

3. Memberikan jawaban ujian yang sama atau menyajikan materi karya tulis sama/hampir sama dapat terjadi karena memanfaatkan hasil teknologi informasi.

Berdasarkan data kelulusan mahasiswa pada Fakultas Ekonomi Universitas Pakuan Bogor untuk tahun ajaran 2009/2010 sampai dengan 2011/2012 penulis mengklasifikasikan ke dalam beberapa kategori kelulusan sebagai berikut:

\begin{tabular}{|c|c|c|c|c|c|c|c|c|c|c|}
\hline \multirow{3}{*}{ No } & \multirow{3}{*}{ Angkatan } & \multirow{3}{*}{$\begin{array}{c}\text { Jumlah } \\
\text { Mhs }\end{array}$} & \multicolumn{8}{|c|}{ Kategori kelulusan } \\
\hline & & & \multicolumn{2}{|c|}{ Lebih Cepat } & \multicolumn{2}{|c|}{ Tepat Waktu } & \multicolumn{2}{|c|}{ Terlambat } & \multicolumn{2}{|c|}{$\begin{array}{c}\text { Sangat } \\
\text { Terlambat }\end{array}$} \\
\hline & & & Jmh & $\%$ & Jmlh & $\%$ & $\begin{array}{l}\mathrm{Jm} \\
\mathrm{lh}\end{array}$ & $\%$ & Jmlh & $\%$ \\
\hline 1 & $2009 / 2010$ & 247 & 37 & 14,98 & 44 & 17,81 & 32 & 12,96 & 134 & 54,25 \\
\hline 2 & $2010 / 2011$ & 303 & 40 & 13,20 & 24 & 7,92 & 27 & 8,91 & 212 & 69,97 \\
\hline 3 & $2011 / 2012$ & 321 & 53 & 16,51 & 29 & 9,03 & & & & \\
\hline
\end{tabular}

Kriteria kategori lulus "Tepat Waktu" apabila mahasiswa dapat menyelesaikan kuliah selama 8 semester, sehingga apabila lulus kurang dari 8 semester dikategorikan sebagai lulus "lebih Cepat" sebaliknya apabila lulus pada semester ke 9 sampai dengan ke10 dikategorikan sebagai lulus "Terlambat" dan apabila lulus lebih dari 10 semester dikategorikan sebagai lulus "Sangat Terlambat". Dari tabel di atas terlihat bahwa untuk mahasiswa angkatan tahun ajaran 2009/2010 jumlah mahasiswa yang dikategorikan sebagai lulus "Lebih cepat" dan "Tepat Waktu" sebanyak
$32,79 \%$, tahun 2010/2011 sebanyak $21,12 \%$ dan tahun 2011/2012 sebanyak $25,54 \%$ sisanya kategori "Terlambat" dan "Sangat Terlambat". Hal tersebut menunjukkan bahwa mahasiswa Fakultas Ekonomi Unpak angkatan tahun 2009/2010 dan 2010/2011 sebagian besar kurang mau bekerja keras/berusaha untuk mempercepat kelulusannya.

Atas dasar uraian tersebut di atas penulis tertarik melakukan penelitian untuk mengetahui apakah mahasiswa yang lulus dengan kategori "Sangat Terlambat" adalah mahasiswa yang tidak 
mau bekerja keras karena mengandalkan pemanfaatan hasil teknologi informasi, atau memanfaatkan secara salah hasil perkembangan teknologi informasi, untuk itu tulisan ini diberikan judul "Analisis Dampak Pemanfaatan Hasil Perkembangan Teknologi Informasi terhadap Tingkat Kelulusan pada Mahasiswa Fakultas Ekonomi Universitas Pakuan Bogor ". Peneliti berharap hasil penelitian ini nantinya dapat diketahui seberapa banyak mahasiswa yang menyalahgunakan hasil perkembangan teknologi informasi dalam proses pembelajaran.

Adapun tujuan penelitian adalah untuk:

1. Mengetahui prakiraan kelulusan mahasiswa angkatan tahun 2009/2010 dan 2010/2011.

2. Mengetahui berapa jumlah mahasiswa angkatan tahun 2009/2010 dan 2010/2011 yang memanfaatkan secara salah hasil teknologi informasi dalam proses pembelajaran.

3. Mengetahui apakah penyalahgunaan hasil perkembangan teknologi informasi pada proses belajar berdampak terhadap tingkat kelulusan mahasiswa.

\section{Kajian Pustaka dan Kerangka Berpikir}

2.1. Informasi

Azhar Susanto $(2004 ; 46)$ dalam bukunya Sistem Informasi Akuntansi, menyatakan bahwa: "Informasi adalah pengolahan data yang memberikan arti dan manfaat". Hal tersebut sesuai dengan yang ditulis Burch dan Strater menyatakan bahwa: "Informasi adalah pengumpulan atau pengolahan data untuk memberikan pengetahuan atau keterangan", demikian juga Raymond McLeod menyatakan bahwa: "Informasi adalah data yang telah diolah menjadi bentuk yang memiliki arti bagi si penerima dan bermanfaat bagi pengambilan keputusan saat ini atau mendatang".

Dengan demikian Informasi adalah merupakan hasil dari proses pengolahan data atau kumpulan fakta. Pengolahan tersebut dapat berupa penyimpanan, pengklasifikasian, penggabungan, merapikan data dlsb, sehingga proses pengolahan informasi merupakan proses mengubah dari bentuk tidak berguna atau mengubah bentuk yang berarti bagi penggunanya untuk mengambil keputusan yang bermanfaat.

Abdul Kadir (2002:31) McFadden, dkk (1999), mendefinisikan informasi sebagai data yang telah diproses sedemikian rupa sehingga meningkatkan pengetahuan seseorang yang menggunakan data. Henry $\mathrm{C}$ Lucas (1194) dalam bukunya Information Concepts for Management mengartikan informasi sebagai "The interpretation of data to provide meaning by an individual" (data yang telah ditafsirkan agar memberikan makna tertentu bagi seseorang.

Dari kutipan atau pendapat para ahli tersebut diatas dapat disimpulkan bahwa informasi adalah data (fakta) yang telah diolah/diproses dengan cara tertentu agar dapat menghasilkan yang digunakan oleh pihak lain untuk bahan pengambilan keputusan yang bermanfaat minimal disebut informasi apabila dapat memberikan manfaat bagi penggunakanya dari semula tidak tahu menjadi tahu.

Dalam hal ini minimal ada dua pihak yang terkait dalam hal informasi yaitu pihak yang menyampaikan informasi dan pihak yang menggunakan informasi.

Ditinjau dari penyampaian informasi dibedakan menjadi tiga yaitu :

1. Informasi yang disampaikan secara berkala 
2. Informasi yang disampaikan setiap saat

3. Informasi yang disampaikan secara mendadak

Ketiga cara penyampaian informasi tersebut di atas dapat terjadi juga dalam penyampaian informasi dalam dunia maya.

\subsection{Teknologi Informasi}

1. Pengertian Teknologi Informasi

Tekonologi

Informasi menyatukan komputasi dan komunikasi berkecepatan tinggi untuk data, suara, dan video. Contoh dari Teknologi Informasi bukan hanya berupa komputer pribadi, tetapi juga telepon, TV, peralatan rumah tangga elektronik, dan peranti genggam modern (misalnya ponsel).

Jadi yang termasuk dalam pengertian Teknologi Informasi semua teknologi meliputi peralatan dan cara yang digunakan untuk mengumpulkan fakta sebagai data, mengolahnya untuk dapat menghasilkan sesuatu yang berguna (informasi), termasuk penyimpanan. Proses pengolahan data/transformasi dari data menjadi informasi termasuk pengadaan dan penggunaan peralatan yang bersifat teknologi antara lain digunakan untuk memperoleh, mentransformasikan,

menyimpan/memelihara dan mengkomunikasi atau menyebarkan informasi.

Sesuai kamus, Teknologi Informasi adalah pengolahan, penyimpanan dan penyebaran vokal, informasi bergambar, teks dan numerik oleh mikroelektronika berbasis kombinasi komputasi dan telekomunikasi (Longley, Dennis, Shain Michael, 1985). Dengan demikian dapat diartikan bahwa
Tekonologi Informasi adalah bidang pengelolaan teknologi dan mencakup berbagai bidang yang termasuk tetapi tidak terbatas pada hal-hal seperti proses, perangkat lunak computer, sistem informasi, perangkat keras computer, bahasa program, dan data konstruksi. Singkatnya, apa yang membuat data, informasi atau pengetahuan yang dirasakan dalam format visual apapun, melalui setiap mekanisme distribusi multimedia, dianggap bagian dari Teknologi Informasi.

Dalam Wikipedia Bahasa Indonesia disebutkan bahwa Teknologi Informasi melakukan berbagai fungsi dari menginstal aplikasi untuk merancang jaringan komputer dan database informasi. Beberapa tugas yang Teknologi Informasi lakukan mungkin termasuk manajemen data, jaringan, rekayasa perangkat keras komputer, pangkalan data (database) dan desain perangkat lunak, serta manajemen dan administrasi sistem secara keseluruhan. Teknologi informasi mulai menyebar lebih jauh dari konvensional berupa komputer pribadi sampai teknologi jaringan, dan lebih ke dalam integrasi teknologi lain seperti penggunaan ponsel, televisi, mobil, dan banyak lagi, yang meningkatkan permintaan untuk pekerjaan.

2. Pemanfaatan Hasil Teknologi Informasi

Perkembangan Teknologi Informasi sedemikian pesat sehingga mampu menghasilkan piranti yang tidak terbatas pada bidang komunikasi saja, melainkan hasil dari rekayasa teknologi informasi berupa peralatan pabrik 
dan peralatan mesin perang yang dapat menggantikan sebagian tugas manusia.

Demikian juga penggunaan teknologi informasi dalam dunia pendidikan tidak hanya terbatas pada penerapan beberapa program aplikasi yang berkaitan dengan administrasi sekolah dan perguruan tinggi oleh Instansi berwenang atau pengelolaan/manajamen

pendidikan sekolah/perguruan tinggi namun juga termasuk program-program animasi yang digunakan mempresentasikan halhal yang rumit untuk dijelaskan dalam dunia pendidikan kondisi tersebut sangat membantu dalam proses pembelajaran bagi murid/mahasiswa.

Dengan adanya hasil perkembangan teknologi informasi sebagian besar orang dapat memperoleh atau mengirim informasi secara cepat dan mudah tanpa dibatasi ruang dan waktu dengan biaya yang terjangkau.

Demikian juga dengan adanya e-booking, e-learning, elaboratory dan e-library, dan hasil dari perkembangan teknologi informasi sangat membantu murid/mahasiswa dapat lebih mudah meningkatkan pengetahuannya dengan cara memanfaatkan peralatan hasil perkembangan teknologi informasi yang pada saat ini dapat dimiliki oleh setiap orang karena selain harganya relatif murah juga mudah dimanfaatkan karena bentuknya yang kecil dan ringan.

Namun dalam kenyataannya hasil perkembangan teknologi informasi juga dimanfaatkan oleh beberapa pihak atau seseorang untuk melakukan hal-hal yang melanggar hukum dan norma yang berlaku contohnya tayangan pornografi, penipuan, fitnah, penyebar kebencian, plagiat dan lain sebagainya. Dengan demikian, perkembangan teknologi Informasi hasilnya dapat dimanfaatkan untuk hal-hal yang positif dan juga negatif atau dapat dikatakan bahwa perkembangan teknolgi informasi selain memberikan dampak yang baik (positif) juga dapat memunculkan dampak tidak baik (negatif).

Heri Susanto (2015), menyebutkan dampak positif dan negatif perkembangan teknologi informasi sebagai berikut:

Dampak positif :
1. Mempermudah dan mempercepat akses informasi yang kita butuhkan.

2. Mepermudah dan mempercepat penyampaian atau penyebaan informasi.

3. Mempermudah transaski perusahaan atau perseorangan untuk kepentingan bisnis.

4. Mempermudah penyelesaian tugas tugas atau pekerjaan.

5. Mempermudah proses komunikasi tidak terhalang waktu dan tempat.

6. Banyak pengunaan teknologi informasi membuka lowongan kerja.

Dampak negatif:

Sisi
negatif dari teknologi
informasi
mudahnya tekarang adalah
sehingga tidak sedikit yang
menyukai bahkan terikat dunia
maya dan melupakan dunia nyata.
Karena teknolog memberikan


banyak kemudahan, tidak sedikit anak anak tidak sabar dalam menghadapi kelambatan dan kesulitan. Dan hal ini juga menimpa pada anak anak terutama pada anak usia 5 hingga 12 tahun.

Selain itu, kemajuan teknologi berdampak pada kurangnya sosialisasi anak pada teman-temannya karena lebih menyukai menyendiri dengan permainan hasil teknologinya. Anak lebih memilih berdiam diri dengan kesibukan sendiri, yaitu game online, browsing gambar atau film dlsb dan interaksi lainnya dari pada bergaul dengan temantemannya yang sebenarnya lebih positif.

Sementara itu dampak negatif perkembangan Teknologi Informasi antara lain, Isu SARA, kekerasan dan pornografi menjadi hal yang biasa. Kemudahan transaksi memicu munculnya bisnis-bisnis terlarang seperti narkoba dan produk black market atau illegal dan kekerasan.

Para penipu dan penjahat bermunculan terutama dalam kasus transaksi online. Munculnya budaya plagiatisme atau penjiplakan hasil karya orang lain.

Dengan demikian dapat diketahui bahwa perkembangan teknologi informasi secara tidak langsung akan berpengaruh terhadap kualitas Sumber Daya Manusia, hal tersebut sangat tergantung sikap penggunanya apakah teknologi informasi akan digunakan untuk hal hal yang positif atau sebaliknya digunakan untuk hal-hal negatif, untuk itu dunia pendidikan harus ikut berperan dalam mengarahkan murid/mahasiswa untuk mendorong/membiasakan para murid/mahasiswa untuk tidak menggunakan hasil perkembangan teknologi informasi untuk hal-hal yang bersifat negatif, sehingga diharapkan dapat menghasilkan generasi yang berintegritas.

2.3. Pembelajaran

Pembelajaran berasal dari kata dasar "belajar", belajar merupakan sebuah proses yang dilakukan oleh seorang individu untuk dapat mengenali dan mengetahui lebih lanjut tentang segala sesuatu yang belum diketahuinya yang berguna bagi hidup dan kehidupannya. Dikatakan proses sebab kegiatan tersebut berlangsung secara terus menerus disadari maupun tidak disadari terjadi di sepanjang hidupnya. Proses belajar dimulai sejak anak lahir sampai tua bahkan sampai meninggal dunia, karena belajar tidak mengenal batasan usia. Kegiatan belajar yang dilakukan sescara teratur pada tempat-tempat tertentu disertai dengan ketentuan yang baku disebut sebagai "pendidikan". Seorang guru Agama Kristen pada salah satu sekolah di Jawa Tengah (2015) menulis tentang pendidikan sebagai berikut: "Pendidikan pada hakekatnya adalah usaha sadar dan terencana untuk mewujudkan suasana belajar dan proses pembelajaran agar peserta didik secara aktif mengembangkan potensi dirinya untuk memiliki kekuatan spiritual keagamaan, pengendalian diri, kepribadian, kecerdasan, akhlak mulia, serta ketrampilan yang diperlukan dirinya masyarakat, bangsa dan Negara".

Dengan demikian pendidikan merupakan bagian dari kegiatan 
belajar yang terencana, terarah untuk mencapai tujuan yang sudah ditetapkan yaitu agar seseorang memiliki kekuatan spiritual dan jiwa, budi pekerti yang tinggi, kecerdasan serta ketrampilan sehingga berguna bagi bangsa dan Negara. Untuk mewujudkan tujuan pendidikan tersebut perlu dilakukan pembelajaran terhadap anak didik secara terus menerus dalam kondisi/suasana belajar. Pendidikan dapat dilaksanakan secara formal dan informal. Pendidikan formal berarti pendidikan yag dilakukan secara terorganisasi, terstruktur, dan miliki sistem, contohnya sekolah dan perguruan tinggi. Sebaliknya pendidikan nonformal kegiatannya dilaksanakan secara tidak terorganisasi, tidak struktur dan tidak memiki sistem yang baku, contohnya pendidikan yang dilaksanakan oleh keluarga dan lingkungan. Dengan demikian sekolah atau perguruan tinggi merupakan lembaga pendidikan yang menyelanggarakan proses pembelajaran kepada anak didik yaitu murid/mahasiswa untuk mencapai tujuan yang sudah ditetapkan, yaitu tidak hanya menjadikan anak didik cerdas dalam menguasai disiplin ilmu tertentu tetapi juga agar anak didik memiliki akhlak atau karakter yang baik.

\subsection{Kerangka Berfikir}

Hasil perkembangan teknologi informasi dapat dimanfaatkan untuk mendukung peningkatan kualitas pembelajaran, contohnya dengan menggunakan LCD Infocus, komputer yang menggunakan program aplikasi animasi dan pengolahan data dapat membuat mahasiswa lebih tertarik dan juga menghemat waktu dan tenaga bagi dosen dalam melaksanakan proses belajar mengajar sehingga dapat terlaksana lebih efektif, di satu pihak mahasiswa lebih mudah menangkap dan mengingat materi pengajaran yang diberikan, terlebih dengan adanya ebook, e-library, di lain pihak para dosen dapat mendapatkan informasi dari internet sehingga memudahkan para dosen meningkatkan pengetahuannya. Namun tidak dapat dipungkiri bahwa perkembangan teknologi juga dapat berdampak negative, yaitu membuat sebagian mahasiswa tidak mau bekerja keras untuk belajar melainkan hanya mengadalkan hasil teknologi informasi.

Pada umumnya mahasiswa mengikuti pendidikan di Perguruan Tinggi bertujuan untuk dapat menyelesaikan pembelajaran (lulus) dengan nilai relatif baik (tinggi). Untuk memperoleh nilai yang tinggi tersebut dapat diperoleh dengan cara jujur atau tidak jujur. Dengan cara jujur berarti mahasiswa harus bekerja keras untuk belajar, mengerjakan tugas tugas dengan sungguh-sungguh secara mandiri atau kelompok, melakukan diskusi dlsb, sedangkan dengan cara tidak jujur yaitu mahasiswa tidak mau bekerja keras atau malas belajar sehingga yang bersangkutan cenderung untuk menghalalkan segala cara, termasuk memanfaatkan hasil teknologi informasi secara salah untuk memperoleh nilai yang baik, dengan demikian mahasiswa yang bersangkutan akan melanggar aturan/ketentuan ataupun norma etika yang berlaku, yaitu mencontek, bertanya kepada teman, menjiplak (plagiat), memberitahu jawaban, browsing mencari jawaban dlsb, dengan menggunakan hasil perkembangan teknologi informasi. Hal tersebut dilakukan oleh mahasiswa karena yang bersangkutan tidak mau bekerja keras sehingga ia lebih memilih menggunakan 
cara-cara yang gampang asalkan dapat mencapai tujuannya, tindakan seperti ini apablla tidak ada upaya untuk membatasi maka lama kelamaan akan menjadi kebiasaaan dan akhirnya menjadi karakter yang akan terbawa terusmenerus sampai ketika ia sudah bekerja.

Salah satu indikator adanya kemauan seorang mahasiwa untuk bekerja keras ditunjukkan dari tingkat ketepatan kelulusan, yaitu semakin banyak jumlah mahasiswa yang kelulusan tidak tepat waktu, menunjukkan masih banyak mahasiswa yang tidak mau bekerja keras untuk belajar.

Memutuskan untuk memanfaatkan secara salah hasil perkembangan teknologi informasi sangat dipengaruhi cara berfikir seseorang atau nilai-nilai yang dimiliki seseorang.

Bagi mahasiswa yang terbiasa melakukan kecurangan dalam proses belajar diperlukan tindakan untuk membatasi/mengurangi atau menangkalnya, karena jika hal tersebut dibiarkan terus menerus maka akan menimbulkan citra yang kurang baik bagi perguruan tinggi, karena dapat menimbulkan anggapan dalam masyarakat bahwa perguruan tinggi tidak berhasil dalam mewujudkan tujuan pendidikan yaitu menghasilkan (output) sumber daya manusia yang berintegritas. Pada umumnya mahasiswa yang tidak mempunyai kemauan berkerja keras cenderung mengandalkan pemanfaatan hasil teknologi informasi dan pada akhirnya tidak dapat menyelesaikan kuliah secara tepat waktu karena kita tahu bahwa keberhasilan memanfaatkan hasil teknologi informasi dalam proses belajar bersifat tidak pasti atau untunguntungan (gambling). Karena itu dalam penelitian ini penulis mencoba untuk mengetahui seberapa banyak mahasiswa yang telah mengenal dan menggunakan hasil perkembangan teknologi informasi dan berapa banyak mahasiswa yang memanfaatkan secara salah hasil perkembangan teknologi informasi dihubungkan dengan prakiraan kelulusannya.

\section{Metodologi Penelitian}

3.1. Jenis Penelitian

Penelitian ini menggunakan penelitian penggambaran (descriptive), yaitu bertujuan untuk menggambarkan atau mendefinisikan suatu fenomena tertentu untuk mengetahui siapa yang berpendapat, apa yang disetujui dan bagaimana cara memanfaatkan.

\subsection{Teknik Pengumpulan Data}

Dalam penelitian ini metode yang akan digunakan adalah metode angket atau kuesioner yaitu sejumlah pertanyaan tertulis yang diajukan kepada responden, digunakan untuk memperoleh informasi apa yang diketahui dan apa yang telah dilakukan. Dengan demikian angket adalah suatu cara pengumpulan informasi dengan penyampaian suatu daftar tentang hal-hal yang diteliti. Angket disusun untuk mendapatkan informasi dari responden utamanya tentang:

1. Prakiraan kelulusan mahasiswa

2. Nilai-nilai perilaku yang dimiliki oleh mahasiswa

3. Pemanfaatan hasil perkembangan teknologi informasi

Pertanyaan yang diajukan disusun dengan menggunakan skala dikotomi (dichotomous scale) untuk jawaban "ya" dan "tidak" dan skala Likert (Likert Scale) dari skala 1 sampai dengan 5 untuk tingkat persetujuaan terhadap sesuatu hal.

\subsection{Teknis Analisis}

Data yang telah dikumpulkan akan diolah dengan beberapa metode analisa data sebagai berikut: 
1) Analisa Kualitatif, yaitu memahami dan menafsirkan setiap data yang ada kaitannya dengan rumusan masalah.

2) Analisa Deskriptif yaitu setelah data terkumpul dilakukan tabulasi data, selanjutnya analisis serta dilakukan interprestasikan berdasarkan logika dan teori yang relevan untuk menarik kesimpulan.

\subsection{Hipotesa}

Untuk memudahkan penarikan kesimpulan hasil pembahasan ditetapkan kesimpulan sementara yang masih perlu diuji kebenarannya sebagai berikut:

H0 : Tidak ada korelasi antara penyalahgunaan hasil teknologi informasi dan perilaku mahasiswa terhadap tingkat kelulusan.

H1 : Ada korelasi antara penyalahgunaan hasil teknologi informasi dan perilaku mahasiswa terhadap tingkat kelulusan.

\subsection{Operasionalisasi Konsep}

\begin{tabular}{|l|l|}
\hline Konsep & Prakiraan Kelulusan Mahasiswa \\
\hline Indikator & Ketepatan kelulusan \\
\hline Ukurannya & Prakiraan lama kuliah, yaitu lebih lama/cepat dari 8 semester \\
\hline Skala & Ordinal \\
\hline & Perilaku \\
\hline Konsep & Nilai-nilai yang dimiliki \\
\hline Indikator & $\begin{array}{l}\text { Tingkat persetujuan terhadap hal-hal yang melanggar norma } \\
\text { dan ketentuan yang berlaku. }\end{array}$ \\
\hline Skala & Ordinal \\
\hline Konsep & Penyalahgunaan hasil Teknologi Informasi \\
\hline Indikator & $\begin{array}{l}\text { Penggunaan hasil teknologi informasi secara salah dalam } \\
\text { proses belajar }\end{array}$ \\
\hline Ukurannya & $\begin{array}{l}\text { Tingkat persetujuan memanfaatkan hasil teknologi informasi } \\
\text { untuk membuat printout contekan, menyalin, mencari } \\
\text { jawaban dari internet, bertanya melalui sms dalam proses } \\
\text { pembelajaran. }\end{array}$ \\
\hline Skala & Ordinal \\
\hline
\end{tabular}

\section{Hasil dan Pembahasan}

4.1. Pengumpulan Data

Dari hasil penyebaran kuesioner kepada 100 orang mahasiswa Fakultas
Ekonomi Program Study Manajemen dan Akuntansi secara acak yang dilakukan pada sekitar bulan April-Mei 2016 sebagai berikut:

\begin{tabular}{|c|c|c|c|}
\hline Program Study & Target (org) & Realisasi (Org) & $\%$ \\
\hline Manajemen & 50 & 50 & 100 \\
\hline Akuntansi & 50 & 50 & 100 \\
\hline Jumlah & 100 & 100 & 100 \\
\hline
\end{tabular}

Adapun hasil dari tabulasi hasil pengumpulan kuesioner sebagai berikut: 
Untuk mengetahui prakiraan kelulusan responden mahasiswa angkatan tahun 2009/2010 dan 2010/2011, dilakukan perhitungan dengan mendasarkan pencapaian pada semester ganjil tahun 2015/2016 yaitu sebagai mahasiswa semester berapa, berapa matakuliah yang masih akan ditempuh dan berapa matakuliah yang masih harus diulang. Atas data tersebut diketahui bahwa prakiraan kelulusan 100 orang responden sebagai berikut:

Tabel 1

Prakiraan Kelulusan

\begin{tabular}{|c|c|c|c|}
\hline Kategori & & Jumlah (Org) & $\%$ \\
\hline Lebih Cepat & : & 17 & 17 \\
\hline Tepat Waktu & : & 49 & 49 \\
\hline Terlambat & $:$ & 27 & 27 \\
\hline Sangat Terlambat & , & 7 & 7 \\
\hline Jumlah & & 100 & 100 \\
\hline
\end{tabular}

Dari Tabel 1 Prakiraan Kelulusan tersebut diatas diketahui bahwa dari 100 orang responden sebagian besar prakiraan kelulusan termasuk dalam kategori "Tepat Waktu" yaitu sebanyak 49 orang atau 49\%, selanjutnya adalah kategori "Terlambat" yaitu sebanyak 27 orang atau $27 \%$ sedangkan kategori kelulusan "Lebih Cepat" sebanyak 17 orang dan sebanyak 7 orang atau $7 \%$ masuk ke dalam kategori "Sangat Terlambat".

\subsubsection{Perilaku}

Untuk mengetahui kebiasaan atau perilaku sehari-hari responden maka responden diminta untuk memberikan persetujuannya atas 42 pernyataan yang diberikan mengenai hal-hal yang berhubungan dengan moral perilaku hidup sehari-hari yang dibuat dalam bentuk skala linkert 1 sampai dengan 5 . Hasilnya dari 100 orang responden menyatakan persetujuannya terhadap pernyataan mengenai bertentangan dengan norma dan peraturan yang berlaku sehingga mencerminkan perilaku seseorang sebagai berikut:

Tabel 2

Perilaku

\begin{tabular}{|l|l|c|c|}
\hline \multicolumn{1}{|c|}{ Kategori } & & Jumlah (Org) & $\%$ \\
\hline Baik & $:$ & 9 & 9 \\
\hline Sedang & $:$ & 81 & 81 \\
\hline Buruk Jumlah & $:$ & 10 & 10 \\
\hline & & 100 & 100 \\
\hline
\end{tabular}

Dari jawaban yang diberikan oleh sebagian besar responden yaitu sebanyak $81 \%$ memilih antara setuju dan tidak setuju atau masuk dalam kategori "sedang" berarti mereka setuju terhadap tindakan-tindakan yang cenderung melanggar norma atau mencerminkan perilaku yang tidak baik. Sedangakan sebagian responden yaitu $10 \%$ pilihannya dapat dikategorikan "buruk" karena mereka setuju untuk menghalalkan segala cara dengan mengesampingkan norma-norma yang berlaku sedangkan sisanya adalah responden yang setuju tetap harus 
mempertahankan norma-norma dan ketentuan yang berlaku hanya $9 \%$.

\subsubsection{Pemanfaatan Teknologi Informasi} Untuk mengetahui sejauh mana responden mengenal hasil perkembangan teknologi informasi telah diajukan beberapa pertanyaan kapan responden mengenal dan bagaimana responden memanfaatkan/menggunakan hasil teknologi informasi tersebut. Dari jawaban yang diberikan oleh 100 orang responden diperoleh hasil sebagai berikut:

Tabel 3

Pengenalan Hasil Teknologi Informasi

\begin{tabular}{|l|c|c|c|}
\hline \multicolumn{1}{|c|}{ Kategori } & & Jumlah (Org) & $\%$ \\
\hline Belum Mengenal & $:$ & 0 & 0 \\
\hline Baru mengenal & $:$ & 1 & 1 \\
\hline Cukup Mengenal & $:$ & 51 & 51 \\
\hline Sangat Familiar & $:$ & 48 & 48 \\
\hline \multicolumn{1}{|r|}{ Jumlah } & & 100 & 100 \\
\hline
\end{tabular}

Dari tabel tersebut di atas diketahui bahwa dari 100 orang responden menyatakan bahwa mereka sudah mengenal dan menggunakan hasil teknologi informasi dan hanya 1 orang responden menyatakan bahwa ia baru mengenal/belum lama menggunakan hasil teknologi informasi, sedangkan sebanyak $51 \%$ mengaku cukup mengenal dan menggunakan dalam waktu cukup lama hasil teknologi informasi dan sisanya $48 \%$ mengaku sudah terbiasa dan jangka waktu relatif lama menggunakan hasil teknologi informasi termasuk penggunaan internet.

Sedangkan untuk mengetahui bagaimana pemanfaatan hasil teknologi informasi oleh 100 orang responden diketahui dari jawaban 25 kuesioner yang diajukan yang berhubungan dengan hal-hal persetujuan mereka terhadap pemanfaatan teknologi informasi dalam mengikuti proses belajar, diperoleh hasil sebagai berikut:

Tabel 4

Pemanfaatan Hasil Teknologi Informasi

\begin{tabular}{|l|c|c|c|}
\hline \multicolumn{1}{|c|}{ Kategori } & & Jumlah (Org) & $\%$ \\
\hline Tidak setuju & $:$ & 6 & 6 \\
\hline Cukup Setuju & $:$ & 74 & 74 \\
\hline Setuju Jumlah & $:$ & 20 & 20 \\
\hline \multicolumn{2}{|c|}{ Jum } & 100 & 100 \\
\hline
\end{tabular}

Dari Tabel 4 yaitu Pemanfaatan Hasil Teknologi Informasi tersebut diatas diketahui dari 100 orang responden menyatakan persetujuaannya terhadap penggunaan hasil teknologi informasi berupa ponsel, Laptop, Tab, Internet pada saat pembelajaran untuk hal-hal yang bertentangan dengan norma atau ketentuan yang berlaku, antara lain mencari tahu jawaban pertanyaan pada saat ujian/test dengan melakukan browsing internet, mencontek, bertanya pada teman dengan menggunakan ponsel/tab, menyalin karya tulis atau sebagian dari karya tulis orang lain tanpa menyebutkan sumbernya, bahwa sebanyak 74 orang responden atau $74 \%$ menyatakan "cukup setuju" dan bahkan 
20 orang responden atau $20 \%$ menyatakan "setuju" dan hanya $6 \%$ responden yang menyatakan "tidak setuju" terhadap penggunaan hasil teknologi informasi untuk hal-hal yang bertentangan dengan norma dan ketentuan yang berlaku.

\subsection{Analisis Pembahasan}

Dari hasil jawaban yang diberikan oleh 100 orang responden terhadap kuesioner yang diajukan dapat disimpulkan sebagai berikut:

1. Sebagian besar responden yaitu sebanyak $49 \%$ diperkirakan lulus dengan kategori "tepat waktu" dan sebanyak $27 \%$ diperkirakan lulus dengan kategori "terlambat" bahkan terdapat sebanyak $7 \%$ termasuk dalam kategori lulus "sangat terlambat" dan hanya $17 \%$ diperkirakan lulus dengan kategori "lebih cepat".

2. Sebagian besar responden yaitu sebanyak $81 \%$ masuk dalam kategori "sedang" berarti yang bersangkutan memiliki nilai-nilai yang biasa hal tersebut ditunjukkan bahwa mereka masih setuju terhadap hal-hal kegiatan yang bertentangan dengan norma dan ketentuan berlaku bahkan sebanyak $10 \%$ responden masuk dalam kategori "buruk" berarti mereka setuju terhadap tindakan yang tidak baik dan hanya sebanyak $9 \%$ responden yang menyatakan bahwa mereka dalam kategori "baik" yang berarti mereka tidak setuju terhadap tindakan yang tidak baik dan masih mempertahankan nilai nilai yang dimiliki.

3. Dari pengenalan terhadap hasil teknologi informasi diketahui sebagian besar yaitu sebanyak $51 \%$ responden menyatakan sudah cukup familiar menggunakan hasil teknologi informasi dalam waktu cukup lama bahkan $48 \%$ responden menyatakan sangat familiar dan telah lama menggunakan hasil teknologi informasi termasuk penggunaan internet. Selanjutnya dari pemanfaatan hasil teknologi informasi diketahui bahwa sebagai besar responden yaitu $74 \%$ di antaranya menyatakan "cukup setuju" apabaila hasil teknologi informasi tersebut digunakan secara salah dalam proses belajar dengan tujuan lulus atau mendapatkan nilai baik dan bahkan sebanyak 20\% responden menyatakan "setuju" menyalahgunakan hasil teknologi informasi walaupun harus melanggar norma atau ketentuan yang berlaku dengan tujuan asal bisa lulus.

Apabila diteliti lagi diketahui bahwa responden yang memberikan pernyataan termasuk dalam kategori "cukup setuju" dan "setuju" untuk pemanfaatan secara salah hasil teknologi informasi adalah responden yang diperkirakan kelulusannya masuk daalam kategori "terlambat" dan "sangat terlambat" dan responden yang termasuk dalam kategori memiliki perilaku " sedang" dan "buruk" diketahui mereka adalah responden yang memberikan pernyataan "setuju" dan "cukup setuju" terhadap penyalahgunaan hasil teknologi informasi.

Berdasarkan hasil pembahasan tersebut diatas dapat dilakukan analisis secara kualitatif sebagai berikut :

a. Mahasiswa yang menyatakan persetujuannya terhadap pemanfaatan hasil teknologi informasi secara salah untuk kategori "cukup setuju" sebanyak $74 \%$ responden dan diantaranya 
termasuk responden dengan prakiraan kelulusan "terlambat lulus" sebanyak 27\%, dengan demikian dapat disimpulkan bahwa pemanfaatan secara salah dapat menghambat tingkat kelulusan mahasiswa.

b. Mahasiswa yang menyatakan persetujuannya terhadap penyalahgunaan hasil teknologi informasi agar dapat lulus untuk kategori "cukup setuju" sebanyak $74 \%$ responden dan persetujuan mahasiswa atas nilai nilai yang mencerminkan perilaku seseorang untuk kategori "sedang" sebanyak $81 \%$, sehingga dapat disimpulkan bahwa perilaku yang kurang baik mempunyai hubungan dengan penyalahgunaan hasil teknologi informasi dalam proses belajar.

Data tersebut jika diolah dengan menggunakan program aplikasi SPSS diperoleh hasil sebagai berikut:

1. Uji normalitas

Hasl dari uji normalitas diperoleh hasil untuk Kolmogorof .200 dan Shapiro Wilk .893 atau > 0.05 sehingga data yang dikumpulkan berupa "data normal".

\section{Korelasi}

Pengujian korelasi antara tingkat persetujuan atas hal penyalahgunaan teknologi informasi terhadap prakiraan kelulusan diperoleh hasil $\mathrm{rs}=.242$ atau terdapat korelasi dan $\mathrm{P}_{-}$value 0.15 atau lebih kecil dari 0,05 sehinggga cukup korelasi di antaranya cukup signifikan

3. Regresi

Untuk pengujian regresi berganda diperoleh hasil $\mathrm{R}=37,9 \% \quad(\mathrm{R}$ square $=14,4 \%$ ), Durbin Watson $=$ 2.212 berarti tidak ada auto correlation. Sedangkan test Anova diperoleh hasil $\mathrm{F}=8.129 \mathrm{P}$ Value
0,001 atau lebih dari 0,05 sehingga dapat disimpulkan hubungan bahwa kedua variabel independen yaitu Tingkat persetujuan atas hal hal yang mencerminkan perilaku dan tingkat persetujuan penyalahgunaan teknologi informasi terhadap prakiraan tingkat kelulusan cukup siginifikan.

Berdasarkan pembahasan secara kualtatif dan statistik dapat disimpulkan bahwa H0 ditolak dan H1 diterima yaitu: Terdapat hubungan yang cukup signifikan antara tingkat perilaku dan tingkat penyalagunaan hasil teknologi informasi dalam pembelajaran terhadap tingkat kelulusan mahasiswa.

\section{Penutup}

\subsection{Kesimpulan}

Dari hasil analisis kualitatif yang dilakukan atas jawaban 100 orang responden yaitu merupakan mahasiswa Fakultas Ekonomi Universitas Pakuan angkatan tahun 2009/2010 dan tahun 2010/2011 diketahui bahwa sebagian besar mahasiswa yaitu sebanyak $74 \%$ cukup setuju untuk menggunakan/memanfaatkan

telpon/tab/computer dalam proses belajar yaitu untuk mendapatkan jawaban ujian atau test/mengerjakan tugas sebab mereka berpendapat bahwa hal tersebut adalah hal yang biasa dan mereka yang memberikan jawaban tersebut adalah sebagian besar mahasiswa yang cukup familiar menggunakan hasil teknologi informasi. Di samping itu juga diketahui bahwa responden dengan prakiraan kelulusan dengan kategori "terlambat" sebanyak $27 \%$ dan kategori kelulusan "sangat terlambat" sebanyak 7\% merupakan responden dengan kategori "cukup setuju" dan "setuju" memanfaatkan secara salah hasil 
teknologi informasi. Dengan demikian dapat disimpulkan bahwa penyalahgunaan hasil teknologi informasi berupa ponsel, tab dan komputer dalam proses belajar terdapat korelasi (hubungan) yang cukup signifikan terhadap tingkat kelulusan mahasiswa.

Dari hasil pembahasan yang telah dilakukan diketahui bahwa sebagian besar responden yang sering menyalahgunakan hasil teknologi informasi dalam proses belajar yaitu sebanyak $74 \%$ adalah responden yang mempunyai perilaku dalam kategori "sedang" yaitu sebanyak $81 \%$, dengan demikian dapat disimpulkan bahwa perilaku yang kurang baik mempunyai korelasi dengan penyalahgunaan hasil teknologi informasi.

Dari statistik dengan menggunakan program SPSS diperoleh hasil sebagai berikut:

1. Uji normalitas diperoleh hasil Kolmogorof .200 dan Shapiro Wilk .893 yang berarti hasilnya > 0.05 dengan demikian data yang dikumpulkan merupakan data "normal".

2. Uji korelasi diperoleh hasil $\mathrm{rs}=$ .242 dan $\mathrm{P}$ value 0.15 atau lebih kecil dari 0,05 sehinggga menunjukkan ada korelasi antara Tingkat Perilaku dan Tingkat Pemanfaatan hasil teknologi informasi terhadap Tingkat Kelulusan yang cukup signifikan.

3. Uji regresi berganda diperoleh hasil $\mathrm{R}=37,9 \% \quad(\mathrm{R}$ square $=$ $14,4 \%)$, Durbin Watson $=2.212$ berarti tidak ada auto correlation. Sedangkan hasil test Anova diperoleh hasil $\mathrm{F}=8.129 \mathrm{P}$ Value 0,001 atau lebih dari 0,05 sehingga dapat disimpulkan hubungan bahwa kedua variabel independen yaitu Tingkat Perilaku dan Tingkat Penyalahgunaan

$\begin{array}{llr}\text { Teknologi } & \text { informasi } & \text { terhadap } \\ \text { Tingkat } & \text { kelulusan } & \text { cukup } \\ \text { siginifikan. } & & \\ & & \end{array}$

\subsection{Saran}

Sehubungan cukup banyaknya mahasiswa Fakultas Ekonomi Universitas yang menyalahgunakan hasil teknologi informasi dalam kegiatan belajar maka dalam rangka menghasilkan output kelulusan mahasiswa yang berintegritas disarankan kepada pimpinan Fakultas Ekonomi Universitas Pakuan untuk membuat kebijakan untuk dapat membatasi penggunaan hasil teknologi informasi dalam ujian atau test serta memperketat pengujian terhadap karya ilmiah mahasiswa untuk membatasi terjadinya plagiat.

\section{DAFTAR PUSTAKA}

Azhar Susanto (2004;46), Sistem Informasi Akuntansi.

Raymond Mc Leod, Sistem Informasi Manajemen, Edisi 10

Abdul Kadir (2202:31); Mc Fadden dkk (1999), Sisem Informasi Manajemen

Henry C Lucas (1194), Information Concepts for Management

Longley, Dennis, Shain Michael, (1985), Kamus Teknologi

Heri Susanto (2015), Dampak Negatif dan Positif Perkembangan Teknologi Dari Usia Dini. 